\title{
A PRELIMINARY STUDY ON ATTITUDE IN ENGLISH AND VIETNAMESE MEDIA TEXTS IN THE LIGHT OF APPRAISAL THEORY
}

\author{
Nguyen Thi Kim Ngan, Nguyen Thi Huong Lan* \\ Faculty of English, Hanoi National University of Education \\ 136 Xuan Thuy, Dich Vong Hau, Cau Giay, Hanoi
}

Received 16 February 2020

Revised 29 April 2020; Accepted 30 May 2020

\begin{abstract}
This paper investigates the use of evaluative language in two articles concerning the destruction of the Earth's largest rainforest, the Amazon, in 2019. The articles were carefully chosen from prominent newspapers, the New York Times in the USA and VnExpress in Vietnam. The analysis of the evaluative language in the two texts was conducted mainly in terms of their attitudes based on the Appraisal Theory by Martin and White (2005). Moreover, White's (1998) systemic linguistic approach was utilized in order to reveal both experiential and interpersonal meanings of news text with the use of lexico-grammar as a tool for analysis. One significant feature of the evaluative language in terms of attitude which was found was the dominance of negativity in both articles regarding the severity of the fire and the passive reactions and scarce solutions to the problems of the local authority. Another conclusion was drawn from the investigation of the two texts was the use of quantification in implied expression of attitude to emphasize the devastation of the Amazon.
\end{abstract}

Keywords: appraisal, evaluative languages, attitudes, news texts, genres

\section{Introduction}

Without doubt, the media cannot stay out of this worldwide phenomenon as "The burning of the Amazon" has continuously been the leading key words in all means of media. Over a short period of time, thousands of articles and news have been published regarding this hot issue, creating such a multinational sensation. It is undeniable that the media all over the world has played a vital role in updating every breaking news to their subscribers and readers. In Vietnam, some prominent newspapers have also made every

* Corresponding author : Tel. : 84- 912766007

Email: lannth@hnue.edu.vn attempt to catch up with their international colleagues in updating news related to the Amazon rainforests.

Although sharing the same topic of the massive burning of the Amazon rainforests, a variety of articles in different countries seem to adopt dissimilar uses of language to address the issue. In order to discover the ideas underlying the words and sentences, it is urgent that discourse analysis is utilized to examine the language in specific articles.

Discourse analysis is often referred to as the analysis of language "beyond sentences". As Cook (1989) defined, "discourse as stretches of language perceived to be meaningful, unified and purposive." Among 
voluminous theories which lay the foundation for discourse analysis, systemic functional linguistics (hereafter SFL) puts emphasis on the notion of language function. Introduced and developed primarily by Michael Halliday in the 1980s, SFL has grown in popularity as one of the most substantial theories on linguistics and applied linguistics. In SFL, the focus point is placed on the function of language, or in other words, how language is used, rather than what language structure is about and the manner by which it is composed (Halliday, 1994). The adoption of SFL can be advantageous when investigating the use of language in particular articles. Systemic Functional Grammar advocates three sorts of metafunctions, namely ideational, interpersonal and textual metafunctions which are interdependent and can affect each other. Among the three proposed metafunctions, interpersonal function is the interaction among participants in oral or written texts.

Within the four categories of interpersonal function, namely modality, mood, intonation and appraisal, the appraisal theory can be helpful in determining the linguistic resources by which a text/speaker comes to express, negotiate and naturalize particular intersubjective and ultimately ideological positions. Consequently, this theoretical theory tends to put concentration on the analysis of 'meaning in context and rhetorical effects rather than grammatical forms due to the fact that grammar and discourse of language are perceived as a set of written or spoken texts that are able to "make" meanings, not as rules to govern structures' (Martin \& Rose, 2008). According to the Appraisal Theory, evaluative language used within the content of a specific text is actually the direct reflection of the author's own ideologies which may be expressed explicitly or implicitly. Attitude is the central system of the appraisal system, through which the speakers/writers' feelings can be revealed and their statuses can be explored. Thus, in this paper, we use the Attitude system within Appraisal Framework as one of our theoretic bases to see the deep meanings of the articles under investigation.

Among different kinds of genres, news stories are used with the highest frequency and they are often highly appreciated in all cultures. This particular genre has woven into everyday life and has played an integrated role no matter in daily life, school education, popular culture or literature. A variety of generic structures of stories can convey numerous differences in terms of their social purposes along with their authors' attitudes and ideologies. Thus, the main aim of this paper is analysing two articles of the same news story genre and the same topic in terms of their evaluative language from the perspective of generic staging based on the Appraisal Theory. The study specifically aims to:

(1) Describe the use of evaluative language in the two articles; and

(2) Compare the use of evaluative language in the two articles and how it can convey the authors' attitudes and ideologies.

\section{Literature review}

\subsection{The Appraisal Theory/Framework}

Established as an extension of the SFL theory by Halliday (1994) and a number of linguists, the Appraisal Theory has its roots from a considerable number of studies conducted by a group of researchers in Australia. Advocates of SFL assume that there are three metafunctions of language, namely ideational, interpersonal and textual. Appraisal belongs to the interpersonal metafunction, the function that indicates relationships among people. 


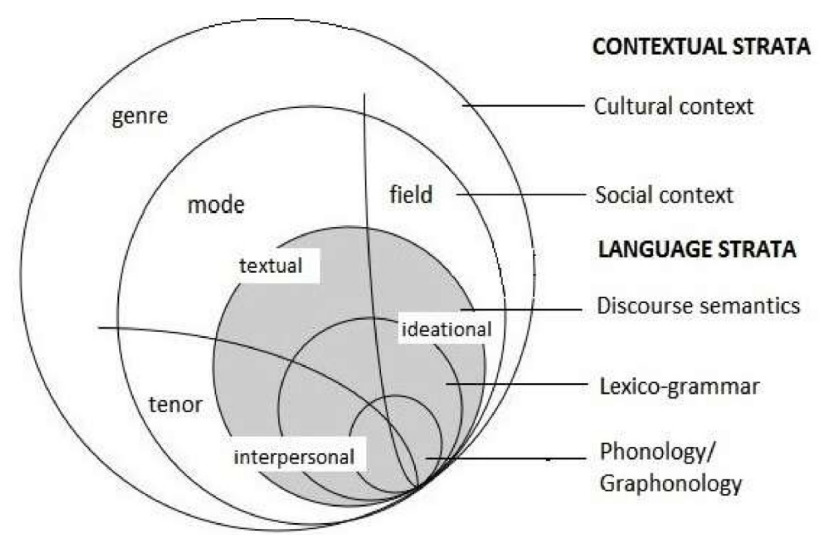

Figure 1. The language stratification and meta-functions (adapted from Martin and White, 2005)

Appraisal, or evaluative language, is a

key term in SFL, discourse analysis and other branches related to applied linguistics. In the Appraisal Theory, it is believed that even in one single sentence, writers or speakers express their approval or disapproval directly or indirectly. Therefore, this theory plays an irreplaceable role in exploring the way language is used to evaluate, adopt stances, construct textual personas and manage interpersonal positioning and relationships. It is also claimed that evaluations of people and events can be perceived accurately through emotions (appraisal). Moreover, appraisal is concerned with "evaluation the kinds of attitudes that are negotiated in a text, the strength of the feelings involved and the ways in which values are sourced and readers aligned" (Martin \& Rose, 2008, p. 25). Mentioning the three fundamental functions of the Appraisal Theory, Hunston and Thompson (2003, p. 6) state that it can express the speaker's or writer's opinions, based on which the value system of that person and their culture and society can be revealed as well. Finally, this theory also plays an important role in constructing and maintaining relations between the speaker/ writer and the listener/reader as well as to organise the discourse.

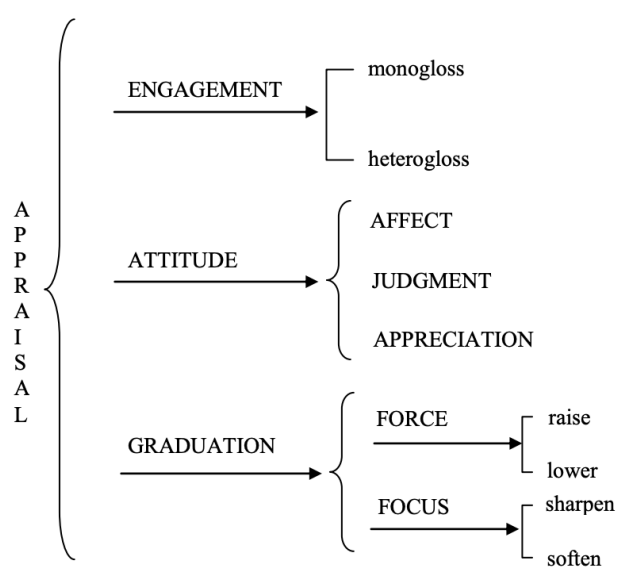

Figure 2: An Overview of Appraisal Resources (Adapted from Martin and White, 2005)

It can be inferred from the given overview of Appraisal Resources taken from Martin and White (2005) above that evaluative language consists of three main factors, engagement, attitude and graduation respectively. Engagement is the category that refers to the resources for introducing voices into a discourse analysis through projection, modalization or concession. This broad term is later divided into two smaller branches, concerning whether the key choice for engagement has to do with voice (monogloss) or more than one voice (heterogloss). The second domain in the Appraisal Resources 
is graduation which is made up of force and focus: the former puts emphasis on the choice to raise or lower the intensity of gradable items while the latter involves the decision of sharpening or softening an experiential boundary.

This paper adopts the remaining category, Attitude, as shown in the theoretical framework. The three components of Attitude are Affect, Judgement and Appreciation as shown hereafter.

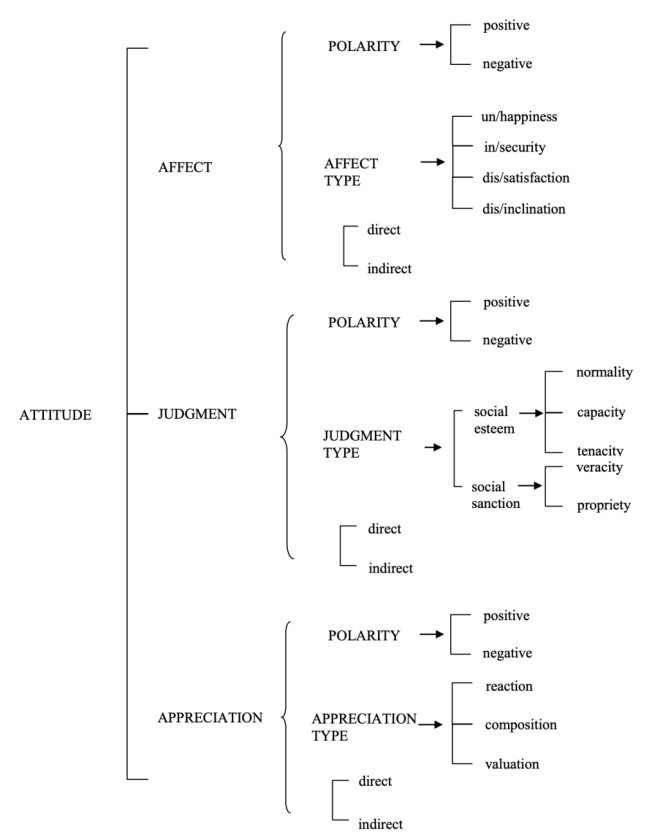

Figure 3: An Overview of Attitude (Adapted from Martin and White, 2005)

Attitude considers a wide range of values thanks to which the authors express judgement and associate emotional/affectual responses with participants and processes. Attitude is classified into three broad categories: affect, judgement and appreciation. Martin and White (2005) claim that the social or relational elements of mentality indicate people's feelings, people's duty to specific guidelines, good standards or people's inclination. Affect is the resource that deals mostly with emotional evaluation. Judgement concerns the assessment or attitudes towards people's character and their behaviors whereas appreciation puts emphasis on the evaluation of the qualities of things and objects. The evaluation can be positive or negative and it can also be delivered directly or indirectly.

Humphrey et al. (2012) provide an outline of some common ways to create implied evaluative meanings: intensification, quantification, repetition and listing, punctuation, figurative language (e.g. metaphor and simile), references to values and icons shared in the community or culture.

\subsection{Genre analysis - Media genres}

In the field of genre studies, the three main schools are Systemic Functional Linguistics, New Rhetoric and English for Specific Purposes (Hyland, 2004).

The purpose of this paper is to identify the interpersonal meaning realized by evaluative languages. White's (1998) systemic linguistic approach which focuses both on experiential and interpersonal meaning of news texts with the use of lexico-grammar as a tool for analysis is adopted.

A news text, on the basis of his approach begins with a headline and lead which act as a nucleus of the news story. The headline/lead is followed by a set of specifications in the body known as elaboration, contextualization, cause-and-effect and appraisal. In the light of the Appraisal Theory, the most noticeable linguistic features of news story genre that can be perceived are affect, judgement and appreciation vocabulary to evaluate the phenomena and grading vocabulary to intensify description. This paper is conducted with a view to examining evaluative language regarding these significant language items as well. 


\subsection{Previous Studies}

Since its introduction as an invaluable guideline for emotion investigation, the Appraisal Theory has attracted increasing interest in numerous fields. Hence, a number of research papers have been conducted using this framework.

In 2012, Soo-Guan Khoo, Nourbakhsh and $\mathrm{Na}$ used the appraisal theory to investigate a collection of political news concerning George W. Bush and Mahmoud Ahmadinejad's economic policies with the overall aim of evaluating the advantages and disadvantages of this theory. On finishing the study, they concluded that the framework was useful in revealing various aspects of sentiment that should be useful to researchers such as the appraisers and object of appraisal, bias of the appraisers and the author, type of attitude and manner of expressing the sentiment. However, there were also a few drawbacks, some of which were problems in identifying appraisal phrases and attitude categories because of the subtlety of expression in political news articles, lack of treatment of tense and time frame, lack of a typology of emotions, and need to identify different types of behaviors (political, verbal and material actions) that reflect sentiment.

In the same year, the appraisal theory was applied in the study of Bippus and Young (2012) which emphasized the way primary and secondary students deal with hurtful messages. Analyzing the appraisal variables, the researchers were able to not only discover the participants' feelings after receiving hurtful messages but also conclude that most of them treated hurt as an outcome instead of an antecedent of the appraisal process. The results also suggested that appraisals could predict the amount of hurt recipients experienced. In terms of the methodological framework, the two writers stressed on the appraisal theory's potential in explaining individuals' responses to hurtful communication.

A few years later, appraisal theory was once again proved a useful framework thanks to Mori's (2017) work. In her article, she praised the effectiveness of such a theory when dealing with evaluation and dialogic voicing in a case study of engagement and dialogism in two undergraduate students writing. The application of this invaluable framework enabled the author to find out the similarities and discrepancies due to students' dissimilar linguistics competences and writing experiences. In her conclusion, she complimented Appraisal theory in the way it provided credible strategies to investigate texts with the purpose of interpreting the linguistic mechanics of such organizations.

In Vietnam, Appraisal Theory has been applied to analyses of texts in both written mode and spoken mode as well. Regarding written discourses in particular, the Appraisal point of view has been adopted to the studies of comparative analysis of English and Vietnamese languages. D. Duy, Vo (2011) conducted doctoral research on style, structure and ideology in English and Vietnamese business hard news reporting. Drawing on Appraisal Theory, the study compares English and Vietnamese business hard news reporting with respect to journalistic voices with a corpus analysis of 50 texts. Later on, T.H. Lan, Nguyen (2019) made a description of language in English and Vietnamese textbooks at primary school level in Singapore and Vietnam, with particular reference to Appraisal, namely the system of Attitude and the system of Graduation. 
The success in the application of appraisal theory in a number of research papers has proved its ability when dealing with the way language is used to evaluate, adopt stances, construct textual personas and manage interpersonal positioning and relationships.

\section{Methodology}

\subsection{Data collection method}

The subject of this paper is two articles concerning the same matter, which is the burning of the Amazon rainforests. One is written in English and the other is in Vietnamese. In order to select the two subjected articles, the author has been reading a number of articles in both languages. One of the most important reasons why the two articles are chosen among a large number of published items is the consideration of the publishers' credibility. The English article is taken from the New York Times website whereas the Vietnamese news is available on Vnexpress.net. The New York Times has long been recognized as one of the most prominent newspapers not only in the USA but also in the whole world. This printing organization is also known to have world-famous and trustworthy reporters and journalists who are always willing to give audience news on the spot. Hence, their articles are often comprehensive and objective once writing about an event or a hot issue. On the other end of the scale, Vnexpress.net is a leading online newspaper in Vietnam. Despite the fact that there are thousands of online sites which update news on a regular basis, VnExpress still owns a stable number of subscribers and avid readers in Vietnam, contributing to its leading position in the media market of Vietnam. The data for this paper is extracted directly from the two articles having the same topic of the catastrophe in the Amazon recently.

\subsection{Research method}

There are two research methods in the world of science which have been utilized to comprehend a horde of phenomenon: the qualitative method and the quantitative method. Concerning the advantages and disadvantages of both research methods in the field of linguistics, this study adopts the qualitative method, which is defined by Strauss and Corbin (1991, p. 11) as "any type of research that produces findings not arrived by statistical procedures or other means of quantification. It can refer to research about persons' lives, lived experiences, behaviours, emotions and feelings as well as organisational functioning, social movements, cultural phenomena, and interactions between them". It can be concluded that the qualitative method puts heavy emphasis on a much deeper understanding of multiple perspectives relating to the subject of the study rather than a set of numbers and figures which now can be delivered by statistical tools or technology within a few minutes or even some seconds.

Based on the previously-mentioned descriptions of this method, it is decided that qualitative is the most appropriate method for this research paper for a number of reasons. Firstly, the fundamental subjects of this paper is the evaluative language in the two chosen texts which can only be recognized by the manual analysis of the words in their own specific contexts. Therefore, an effective method for this study must be one that can produce in-depth and detailed information for comprehensive understanding of 
various dimensions of the words under analysis. As a result, the qualitative method has proved itself to be a competent tool when dealing with deeper meanings of the words in general, and evaluative language in particular. Moreover, the process of identifying evaluative features has not yet been quantified despite considerable efforts given by worldwide scholars throughout the years, which contributes to the superiority of the qualitative one in this research paper. Utilizing qualitative approach here is beneficial as any language assessment cannot be set apart from context, culture and values of where it was used (McNamara, 2003).

The qualitative method was adopted in two stages. For the first stage, each article was put into Microsoft Word. The Attitude of each article was investigated manually following the same model of description, which is the Appraisal Framework (Martin and White, 2005). Each article was examined individually, using the color coding system in order to show whether the attitude belongs to Affect, Judgement or Appreciation. The language items was also investigated based on whether they were used in positive $(+v e)$ or negative (-ve), direct or indirect ways.

After analyzing the articles separately, a manual comparison was be carried out to show the similarities and differences between the English and Vietnamese texts, which is also the second stage using qualitative method. It is uncontroversial that even though talking about the same topic, each writer will have his own way of using evaluative language in order to convey his ideas. Therefore, putting these two articles under comparison will be likely to result in better understanding of the authors or the newspapers' opinion over this natural disaster.

\section{Findings and discussion}

4.1. The analysis of evaluative languages in the English article

\subsubsection{Direct attitudes}

Each article makes use of resources from each of the three categories of attitude. The explicit attitudes are categorized below using different color coding systems. Pink is used to mark words and expressions which tell us the feelings of the writer or character (affect); blue is used to mark words and expressions which judge the behavior or personality of the author or character (judgement) and green is used to mark words and expressions which evaluate the qualities of things (appreciation). In the table, what or who is evaluated and the source of evaluation (if it is given) are demonstrated in bold as well. "+ve" and "-ve" are also added to indicate whether positive or negative evaluation is being made. 
Table 1. Identifying explicit attitudes in the English article

\begin{tabular}{|c|c|c|}
\hline & Extract from Text & Types of attitudes \\
\hline 1 & Wildfires raging in the Amazon rainforest have jumped this year, & Affect (-ve) \\
\hline 2 & $\begin{array}{l}\text { The surge marks an } 83 \% \text { increase over the same period of } 2018 \text {, the agency } \\
\text { said on Tuesday, }\end{array}$ & Appreciation (-ve) \\
\hline 3 & and is the highest since 2010 . & Appreciation (-ve) \\
\hline 4 & $\begin{array}{l}\text { as concerns grow over right-wing President Jair Bolsonaro's environmental } \\
\text { policy. }\end{array}$ & Affect (-ve) \\
\hline 5 & $\begin{array}{l}\text { Amazonas declared an emergency in the south of the state and in its capital } \\
\text { Manaus on August. }\end{array}$ & Affect (-ve) \\
\hline 6 & Wildfires are common in the dry season, & Affect $(+v e)$ \\
\hline 7 & Wildfires have increased in Mato Grosso and Para, & Appreciation (-ve) \\
\hline 8 & $\begin{array}{l}\text { but are also deliberately set by farmers illegally deforesting land for cattle } \\
\text { ranching. }\end{array}$ & Judgment (-ve) \\
\hline 9 & The unprecedented surge in wildfires & Affect (-ve) \\
\hline 10 & ignoring international concern over increased deforestation. & Judgment (-ve) \\
\hline 11 & Asked about the spread of uncontrolled fires, Bolsonaro brushed off criticism & Appreciation (-ve) \\
\hline 12 & $\begin{array}{l}\text { Space agency INPE, however, said the large number of wildfires could not } \\
\text { be attributed to the dry season or natural phenomena alone. There is nothing } \\
\text { abnormal about the climate this year or the rainfall in the Amazon region }\end{array}$ & Appreciation (+ve) \\
\hline 13 & $\begin{array}{l}\text { "The dry season creates the favorable conditions for the use and spread } \\
\text { of fire, but starting a fire is the work of humans, either deliberately or by } \\
\text { accident," Setzer said. }\end{array}$ & Appreciation (-ve) \\
\hline 14 & $\begin{array}{l}\text { People frequently blame the dry season for the wildfires in the Amazon, but } \\
\text { that is not quite accurate, he said. }\end{array}$ & Appreciation (-ve) \\
\hline 15 & $\begin{array}{l}\text { but starting a fire is the work of humans, either deliberately or by accident," } \\
\text { Setzer said. }\end{array}$ & Judgement (-ve) \\
\hline 16 & Bolsonaro recently fired the director of INPE after he criticized agency statistics & Judgement (-ve) \\
\hline 17 & $\begin{array}{l}\text { Bolsonaro recently fired the director of INPE after he criticized agency } \\
\text { statistics showing an increase in deforestation in Brazil, saying they were } \\
\text { inaccurate. }\end{array}$ & Appreciation (-ve) \\
\hline 18 & If they are alarming, I will take notice of them in front of you," he told reporters. & Judgement (-ve) \\
\hline
\end{tabular}

As it can be inferred from the table above, among the three components of attitude that can be detected directly, appreciation is used with the highest frequency. Affect comes at the second place and finally judgement. Affect is utilized mostly to describe straightforwardly the worries and concerns of people from all over the world over this issue. Language items belonging to affect also demonstrates that fact that the situation is getting worse and worse in the Amazon as the fire keeps on spreading. On the other hand, judgement is found to have the aim of talking about people's actions during the fire.

One of the most noticeable features of the evaluative language items in this article is the 
prevalence of the negative evaluation. Among 20 extracts taken from the article, only two of them are positive, and the rest eighteen are negative. Based on the taken extracts, the negative attitude is utilized whenever the severe destruction of the Amazon rainforests is mentioned.

Negativity also appears when it comes to the reactions of the Brazil government to this natural calamity, or when they are being asked about the real cause of such a debacle. The only positive extract found within 20 taken ones is the one that claims about the normal natural condition of the Amazon, saying that there is nothing unusual regarding the natural features of the world's largest rainforest.

\subsubsection{Indirect expressions of attitude}

Along with the transparent evaluation made in the text, a number of implied expressions are found within the content of the English article, which is demonstrated in Table 2 as follows:

Table 2. Identifying implied expressions of attitudes in the English article

\begin{tabular}{|c|c|c|c|}
\hline & Indirect expression of attitude & Resource & Attitude meaning \\
\hline 1 & $\begin{array}{l}\text { Wildfires raging in the Amazon rainforest have } \\
\text { jumped this year }\end{array}$ & Figurative Language & (-ve) Judgement \\
\hline 2 & $\begin{array}{l}\text { with } \underline{72,843 \text { fires }} \text { detected so far by Brazil's } \\
\text { space research centre INPE }\end{array}$ & Quantification & (-ve) Appreciation \\
\hline 3 & as concerns grow over right-wing & Figurative language & (-ve) Judgement \\
\hline 4 & $\begin{array}{l}\text { The surge marks an } \underline{\mathbf{8 3 \%}} \text { increase over the same } \\
\text { period of } 2018\end{array}$ & Quantification & (-ve) Appreciation \\
\hline 5 & $\begin{array}{l}\text { INPE said satellite images spotted } 9,507 \text { new } \\
\text { forest fires in the country }\end{array}$ & Quantification & (-ve) Appreciation \\
\hline 6 & $\begin{array}{l}\text { INPE said satellite images spotted 9,507 new } \\
\text { forest fires in the country, mostly in the Amazon } \\
\text { basin, home to the world's }\end{array}$ & Intensification & (-ve) Appreciation \\
\hline 7 & $\begin{array}{l}\text { Amazonas declared an emergency in the south } \\
\text { of the state }\end{array}$ & $\begin{array}{ll}\begin{array}{l}\text { References to shared } \\
\text { values }\end{array} & \\
\end{array}$ & (-ve) Judgement \\
\hline 8 & $\begin{array}{l}\text { Images show the northernmost state of } \underline{\text { Roraima }} \\
\text { covered in dark smoke. Amazonas declared an } \\
\text { emergency in the south of the state and in its } \\
\text { capital } \underline{\text { Manaus }} \text { on Aug. } 9 \text {. Acre, on the border } \\
\text { with } \underline{\text { Peru }} \text {, has been on environmental alert } \\
\text { since Friday due to the fires. }\end{array}$ & Listing & (-ve) Judgement \\
\hline 9 & $\begin{array}{l}\text { but are also } \underline{\text { deliberately }} \text { set by farmers illegally } \\
\text { deforesting land for cattle ranching. }\end{array}$ & Intensification & (-ve) Judgement \\
\hline 10 & $\begin{array}{l}\text { ignoring international concern over increased } \\
\text { deforestation. }\end{array}$ & Quantification & (-ve) Appreciation \\
\hline 11 & $\begin{array}{l}\text { Bolsonaro took office in January vowing to } \\
\text { develop the Amazon region }\end{array}$ & References to share values & (-ve) Judgement \\
\hline
\end{tabular}




\begin{tabular}{|c|c|c|c|}
\hline 12 & $\begin{array}{l}\text { Bolsonaro brushed off criticism, saying it was } \\
\text { the time of the year of the "queimada" or burn, } \\
\text { when farmers use fire to clear land }\end{array}$ & $\begin{array}{l}\text { References to shared } \\
\text { values }\end{array}$ & (+ve) Appreciation \\
\hline 13 & 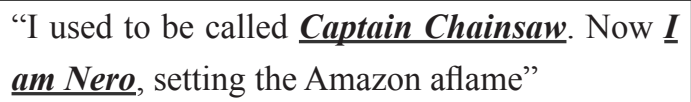 & $\begin{array}{l}\text { References to shared } \\
\text { values }\end{array}$ & (-ve) Judgement \\
\hline 14 & $\begin{array}{l}\text { said the large number of wildfires could } \\
\text { not be attributed to the dry season or natural } \\
\text { phenomena alone }\end{array}$ & Quantification & (-ve) Judgement \\
\hline 15 & $\begin{array}{l}\text { wildfires could not be attributed to the dry } \\
\text { season or natural phenomena alone }\end{array}$ & Quantification & (-ve) Appreciation \\
\hline 16 & which is just $\underline{\text { a little below average," }}$ & Quantification & (+ve) Appreciation \\
\hline 17 & $\begin{array}{l}\text { People frequently blame the dry season for the } \\
\text { wildfires in the Amazon }\end{array}$ & Intensification & (-ve) Judgement \\
\hline 18 & Bolsonaro recently fired the director of INPE & $\begin{array}{l}\text { References to shared } \\
\text { values }\end{array}$ & (-ve) Judgement \\
\hline 19 & $\begin{array}{l}\text { I will take notice of them in front of you," he } \\
\text { told reporters }\end{array}$ & $\begin{array}{l}\text { References to shared } \\
\text { values }\end{array}$ & (-ve) Judgement \\
\hline 20 & showing an increase in deforestation in Brazil & Quantification & (-ve) Appreciation \\
\hline
\end{tabular}

Taking into consideration the implied expressions of attitude, quantification is likely to be used with the highest frequency. References to shared values come at the second place and then intensification, figurative language and listing. Similarly to direct expressions which have been discussed above, negative language is used much more than positive one. Regarding the three categories of attitude, affect is not used even once whereas judgement appears the most with 11/20 times of appearance. Appreciation is at the second place in the rank of frequency with 9 times appearing over 20 extracts from the text.

It can be inferred from the aforementioned statistics that the Western paper uses two main groups of quantifiers with different purposes. The first are those describing large quantities such as "the large number", "mostly", etc. to describe the escalation in the worrying spread and damages of the fires to the Amazon. On the other hand, expressions depicting small quantities like "a little", "alone", etc. serve as indicators for the idle reactions to the catastrophes of authorities. Another feature related to quantification that is worth noticing is the integration of exact statistics and places such as "72,843 fires", "9,507 new forest fires", " $83 \%$ increase", Roraima, Amazonas, Manaus, Peru, etc. The emergence of such truthful data contributes greatly to the disastrous picture of what is happening in Amazon forests and these numerical values may leave a strong impression in readers' minds.

\subsection{The analysis of evaluative languages in the Vietnamese article}

\subsubsection{Explicit attitudes}

The same color coding process is applied in the analysis of the evaluative language in the article published by VnExpress. Pink, blue, and green are used to mark affect, judgement and appreciation respectively. The source of evaluation (if it is given) is demonstrated in bold as well. "+ve" and "-ve" are also added to demonstrate whether positive or negative evaluation is being formed. 
Table 3. Identifying explicit attitudes in the Vietnamese article

\begin{tabular}{|c|c|c|}
\hline & Extract from Text & Type of Attitude \\
\hline 1 & $\begin{array}{l}\text { Gần } 79.000 \text { vu cháy rừng đã được ghi nhận ở Brazil trong năm nay, cao } \\
\text { nhất kề từ năm } 2013\end{array}$ & Appreciation (-ve) \\
\hline 2 & nơi được coi là "lá phổi xanh" của hành tinh. & Appreciation (+ve) \\
\hline 3 & $\begin{array}{l}\text { riêng hai ngày } 23 \text { và } 24 / 8 \text { đã có hơn } 1.600 \text { đám cháy mới tiếp tục bùng } \\
\text { phát tại Amazon. }\end{array}$ & Judgement (-ve) \\
\hline 4 & $\begin{array}{l}\text { Tuần trước, khói và tro từ đám cháy rừng thậm chí bay qua } 2.735 \mathrm{~km} \text { tới } \\
\text { thành phố Sao Paulo, nhuộm đen bầu trời vào ban ngày. }\end{array}$ & Judgment (-ve) \\
\hline 5 & $\begin{array}{l}\text { Bang Rondonia là một trong những nơi chịu ảnh hưởng nặng nề nhất } \\
\text { trong thảm họa cháy rừng, khi người dân phải chung sông với màn khói } \\
\text { mù mịt. }\end{array}$ & Appreciation (-ve) \\
\hline 6 & khi người dân phải chung sống với màn khói mù mịt. & Appreciation (-ve) \\
\hline 7 & $\begin{array}{l}\text { Các chuyên gia cho hay việc người dân địa phương phá rừng để làm } \\
\text { nương rây hoặc chăn thả gia súc trong những tháng mùa khô đã khiến tình } \\
\text { trang cháy rừng trở nên nghiêm trọng hơn. }\end{array}$ & Affect (-ve) \\
\hline 8 & $\begin{array}{l}\text { Copernicus, chương trình vệ tinh của Liên minh châu Âu, chia sẻ bản đồ } \\
\text { cho thấy khói lan tới vùng ven biển Đại Tây Dương của Brazil }\end{array}$ & Judgement (-ve) \\
\hline 9 & $\begin{array}{l}\text { bao phủ gần nửa đất nước và tràn sang các quốc gia láng giềng Peru, } \\
\text { Bolivia và Paraguay. }\end{array}$ & Judgement (-ve) \\
\hline 10 & dù chính phủ của ông bị chỉ trích là phản ứng chậm chạp trước thảm họa & Judgment (-ve) \\
\hline 11 & $\begin{array}{l}\text { Tổng thống Bolsonaro hôm } 21 / 8 \text { đổ lỗi cho các tổ chức phi chính phủ } \\
\text { gây ra các vụ cháy }\end{array}$ & Judgement (-ve) \\
\hline 12 & ông nói rằng các nông dân có thể là thủ phạm dẫn tới thảm họa này. & Judgement (-ve) \\
\hline 13 & $\begin{array}{l}\text { Thảm hoa ở rừng mưa lớn nhất thế giới đang gây ra một làn sóng phẫn } \\
\text { nộ toàn cầu, }\end{array}$ & Affect (-ve) \\
\hline 14 & $\begin{array}{l}\text { các lãnh đạo của nhóm các nước công nghiệp phát triển, đã nhất trí } \\
\text { hố trợ càng sớm càng tốt những quốc gia chịu ảnh hưởng do cháy rừng } \\
\text { mưa ở Amazon }\end{array}$ & Affect (-ve) \\
\hline 15 & $\begin{array}{l}\text { Tổng thống Mỹ Donald Trump và Thủ tướng Anh Boris Johnson } \\
\text { trước đó cũng đã đề nghị giúp đỡ Brazil khống chế thảm họa cháy rừng. }\end{array}$ & Affect $(+v e)$ \\
\hline
\end{tabular}

Among the 15 excerpts taken from the Vietnamese article, judgement seems to outweigh the other two categories with the highest frequency of 7 . Appreciation and affect both appear four times. The sources of evaluation are stated clearly in most extracts, contributing to the credibility of the assessment in particular and the article in general. One noticeable feature of attitudes in this article is the dominance of negative evaluation with 13 out of 15 expressions being made negatively compared to only 2 positive assessments. The implication of such evaluative language choice is that the Vietnamese article concerns more about the people involved in the fires. 


\subsubsection{Implied expressions of attitude}

Table 4. Identifying implied expressions of attitudes in the Vietnamese article

\begin{tabular}{|c|c|c|c|}
\hline & Indirect expression of attitude & Resource & Attitude meaning \\
\hline 1 & $\begin{array}{l}\text { Rừng Amazon ở Brazil hứng chịu hàng nghìn đám } \\
\text { cháy, }\end{array}$ & Quantification & (-ve) Appreciation \\
\hline 2 & khiến khói lan rộng $\underline{\text { môt } \boldsymbol{n} \text { nưa đất nước, }}$ & Quantification & (-ve) Judgement \\
\hline 3 & $\begin{array}{l}\text { Gần } \underline{79.000} \text { vụ cháy rừng đã được ghi nhận ở Brazil } \\
\text { trong năm nay }\end{array}$ & Quantification & (-ve) Appreciation \\
\hline 4 & nơi được coi là “lá phổi xanh" của hành tinh & Punctuation & (+ve) Appreciation \\
\hline 5 & $\begin{array}{l}\text { riêng hai ngày } 23 \text { và } 24 / 8 \text { đã có hơn } \underline{1.600 \text { đám cháy }} \\
\text { mới tiếp tục bùng phát tại Amazon. }\end{array}$ & Quantification & (-ve) Appreciation \\
\hline 6 & khi người dân phải chung sống với màn khói mù mịt. & Figurative Language & (-ve) Judgement \\
\hline 7 & $\begin{array}{l}\text { diện tích rừng mưa Amazon bị phá hủy mỗi phút lớn } \\
\text { hơn } 1,5 \text { sân bóng đá. }\end{array}$ & Figurative Language & (-ve) Judgement \\
\hline 8 & $\begin{array}{l}\text { Tuần trước, khói và tro từ đám cháy rừng thậm chí } \\
\text { bav qua } 2.735 \mathrm{~km} \text { tới thành phố Sao Paulo }\end{array}$ & Quantification & (-ve) Judgement \\
\hline 9 & nhuộm đen bầu trời vào ban ngày. & Figurative Language & (-ve) Judgement \\
\hline 10 & $\begin{array}{l}\text { cho thấy khói lan tới vùng ven biển Đại Tây Dương } \\
\text { của Brazill, bao phủ gần nửa đất nước và tràn sang } \\
\text { các quốc gia láng giềng } \underline{\text { Peru, Bolivia và Paraguay. }}\end{array}$ & Listing & (-ve) Judgement \\
\hline 11 & 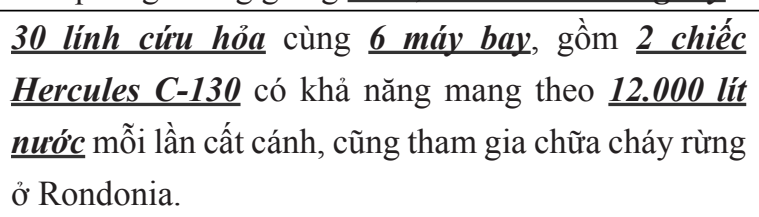 & Listing & (+ve) Appreciation \\
\hline 12 & $\begin{array}{l}\text { Thảm họa ở rừng mưa lớn nhất thế giới đang gây ra } \\
\text { một làn sóng phẫn nộ toàn cầu }\end{array}$ & Intensification & (-ve) Appreciation \\
\hline 13 & $\begin{array}{l}\text { làm dấy lên các cuộc biểu tình thu hút hàng nghìn } \\
\underline{\text { người ở Brazil lẫn các nước châu Âu }}\end{array}$ & Quantification & (-ve) Judgement \\
\hline
\end{tabular}

The information delivered by Table 4 illustrates the ascendancy of quantification in implied expressions of Attitude with nearly half of the expressions found are under this category. Figurative language and listing come at the second and third place with three and two detected expressions respectively. Finally, punctuation appears only once within the content of the Vietnamese article.

It can be inferred from the summary of Table 4 above that quantifiers are applied with a high frequency when emphasizing the casualties caused by this incident. The existence of numbers with high values indicate the seriousness of the current situation in the Amazon and it also suggests there should be solutions immediately to stop this natural disaster.

\subsection{The deployment of evaluative languages in the two articles}

\subsubsection{Explicit Attitudes}

The two articles picked from The New York Times and VnExpress share some common features regarding the use of explicit attitudes. The most noticeable similarity is 
the dominance of negativity evaluation over positive one. It is detected that negativity is often created when both articles mention the catastrophic conditions of the Amazon rainforests and the passive reactions of the Brazil government. On the other hand, positive language is made when it comes to the importance of the world's largest tropical forest and the efforts to extinguish the fire.

Despite some similarities, the two articles have their own ways of expressing their explicit attitudes. The most frequently-used category of attitude in the English text is appreciation whereas it is judgement in the Vietnamese one. Moreover, affect is applied with a higher frequency in the text by the New York Times than in the text by VnExpress.

\subsubsection{Implied Expressions of Attitude}

A number of indirect evaluations of attitude are found in the two articles, contributing immensely to the efficiency of the evaluative language in both texts. Judgement and appreciation are the two categories that are used a lot of times whereas affect is hardly seen in this underlain section. A remarkable similarity in the use of hidden evaluation in the two chosen texts is the plentifulness of quantification in order to intensify the troublesome situation in the Amazon. Listing and intensification appear in both texts, but only once or twice. In addition to that, the same as in direct evaluation, negative attitude outweighs the positive, indicating that both articles share a common pessimistic viewpoint about the conditions of the rainforests.

However, there are some differences between the use of indirect elements in the two articles. Firstly, the application of references to shared values can only be detected within the content of the New York Time's text whereas none is found in the VnExpress's text. On the contrary, only the Vnexpress' paper uses punctuation to imply the importance of the Amazon rainforests. Figurative language is detected in both texts. This kind of indirect evaluation is used in the English text with a view to emphasizing increasing worries about this natural emergency whereas in the Vietnamese it is used mostly to describe the uncontrollable spread of the fire and the sufferings of the people in the nearby areas.

\subsection{How interpersonal meaning is conveyed through evaluative languages in the two texts}

Considering all the previously-mentioned data and analysis, several interpersonal meanings can be interpreted from the evaluative language in the two texts.

First of all, the dominant negativity in both articles strongly emphasizes the seriousness of what is happening in the Amazon. Both authors transparently show their concerns and worries about this natural disaster, indicating the fact that this problem is no longer nationwide, but it is a worldwide threat to every nation on Earth. The writers of both articles make use of a large number of quantifiers to intensify the large scale and the increasing damage and spread of the fire, implying the fact that the problem is still under control and it does not seem to be over yet. The alarming situation has been depicted vividly and comprehensively thanks to the evaluative language made by the two writers. Negative evaluation is also detected when mentioning the efforts that have been made to save our rainforests. Therefore, it can be inferred that the problem has not yet been given adequate awareness and attention by the local government, or on a larger scale, by the whole world. Despite the fact that some actions have been taken in order to tackle the problem, it seems that too little has been done compared to what actually is occuring in the rainforests, given thousands and thousands of new fires nowadays.

Affect, the category of attitude that shows feelings of the authors or the characters, is often utilized to demonstrate the feelings of other people related to the incident, not the author himself. As a result, it is indicative 
that reporting such a worldwide phenomenon demands the writer to be as objective as he can, showing no personal opinions or subjective comments on the issue. The case is more obvious in the Vietnamese article, with no personal evaluation being made by the author, who is only reporting neutrally what is happening without giving any evaluation.

Between the two articles, only the English one quoted the Brazilian's authorities and other related people's words whereas the Vietnamese only reported indirectly without quoting anyone. It seems the English article is taking advantage of what people say directly to form evaluative language while the article written in Vietnamese does not want to mention anyone specifically. The discrepancy between the two articles may result from the differences in the East and the West cultures. In Western countries, the media can evaluate even the person who is leading the country just as McQuail (2006) concluded that one of the most important roles of media in Western countries is to help raise the voice of the public to reach political authorities and vice versa. On the contrary, people in the East tend to report only the news without attributing the responsibility for anyone publicly to the newspapers. Therefore, it is often avoidable in Vietnam to use a person's words directly in order to evaluate his/her comments over the matter, especially such a sensitive problem which receives the attention of billions of people like the burning of the Amazon rainforests. In contrast, the New York Times tends to exploit the Brazilian government's announcement to indirectly make evaluation about it.

\section{Conclusion}

The analysis of the two texts under the Appraisal Theory by Martin and White (2005) have revealed noticeable evaluative language factors in terms of attitude. The most significant feature is the pre-eminence of negativity in both articles when describing the severity of the fire and the slow reactions and solutions to the problems of the local authority. Another language element that is worth considering is the use of quantification in implied expression of attitude in order to emphasize the serious destruction of the Amazon.

This is a preliminary research in a bigger project. This paper, therefore, has some limitations. Firstly, the two texts with approximately 1000 words are not large enough for the findings to be highly generalized. Not to mention the fact that they are just two in several texts which have been published concerning the same topic. Hence, the evaluative language discussed may not be the same in other texts of the same genre.

It is proposed that further research should be taken with a larger corpus in order to achieve a more objective and accurate result. This study only took two among many articles from various newspapers, so the materials left are abundant and can be taken great advantage of. Furthermore, the authors only devote to interpreting the Attitude in the Appraisal Theory whereas there are other noticeable features in the framework. Therefore, a closer look into those left-behind items will be addressed in future research.

\section{References}

Bippus, A. M., \& Young, S. L. (2012). Using Appraisal Theory to Predict Emotional and Coping Responses to Hurtful Messages. Interpersona: An International Journal on Personal Relationships, 6(2), 176-190. https://doi.org/10.5964/ijpr.v6i2.99

Cook, G. (1989). Discourse (Nachdr.). Oxford University Press.

Halliday, M. A. K. (1994). An introduction to functional grammar (2nd ed). E. Arnold.

Humphrey, S., Droga, L., \& Feez, S. (2012). Grammar and meaning: a new edition. Newtown PETAA.

Hunston, S., \& Thompson, G. (Eds.). (2003). Evaluation in text: Authorial stance and the construction of discourse (Reprinted). Oxford Univ. Press.

Hyland, Ken. (2004) Genre and Second Language 
Writing. Ann Arbour: The University of Michigan Press.

Martin, J., \& Rose, D. (2008). Genre Relations: Mapping Cultures.

Martin, J. R., \& White, P. R. R. (2005). The language of evaluation: Appraisal in English. New York: Palgrave Macmillan.

McNamara, T. (2003). Tearing us apart again: The paradigmwars and the search for validity. EUROSLA Yearbook, 3, 229-238. https://doi.org/10.1075/eurosla.3.13mcn

McQuail, D. (2006). Media roles in society. Tartu University Press.

Mori, M. (2017). Using the Appraisal framework to analyze source use in essays: A case study of engagement and dialogism in two undergraduate students' writing. Functional Linguistics, 4(1), 11. https://doi.org/10.1186/ s40554-017-0046-4

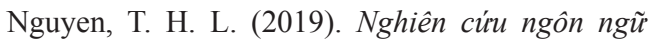
đánh giá trong sách giáo khoa bậc tiểu học (So sánh sách Tiếng Anh tiểu học ở Singapore và sách tiếng Việt tiểu học ở Việt Nam) (A study of Language of Evaluation in Primary School Level Textbooks (A comparison of English and Vietnamese language textbooks in Singapore and Vietnam)

Soo-GuanKhoo, C., Nourbakhsh,A., \&Na, J. (2012). Sentiment analysis of online news text: A case study of appraisal theory. Online Information Review, 36(6), 858-878. https://doi.org/10.1108/14684521211287936

Strauss, A. L., \& Corbin, J. M. (1991). Basics of qualitative research: Grounded theory procedures and techniques (3. printing). Sage.

Vo, D. D. (2011). Style, structure and ideology in English and Vietnamese business hard news reporting: A comparative Study.

White. P. R. R. (1998). Telling media tales: the news story as rhetoric. (PhD thesis). Sydney: University of Sydney.

\title{
NGHIÊN CÚU BƯỚC ĐÀ̀U VỀ THÁI ĐỘ TRONG BẢN TIN TIẾNG ANH VÀ TIÊNG VIÊT NHÌN TÙ GÓC ĐỘ LÝ THUYẾT ĐÁNH GIÁ
}

\author{
Nguyễn Thị Kim Ngân, Nguyễn Thị Hương Lan \\ Khoa tiếng Anh, truờng Đại học Su phạm Hà Nội \\ 136 Xuân Thủy, Dịch Vọng Hậu, Cầu Giấy, Hà Nội, Việt Nam
}

Tóm tắt: Bài viết nghiên cứu việc sử dụng ngôn ngữ đánh giá trong hai bài báo liên quan đến việc phá hủy rừng nhiệt đới lớn nhất Trái đất, Amazon, vào năm 2019. Đây là hai bài báo đã được lựa chọn cẩn thận từ hai tờ báo nổi tiếng, New York Times ở Hoa Kỳ và VnExpress tại Việt Nam. Việc phân tích ngôn ngữ đánh giá trong hai văn bản được thực hiện chủ yếu theo thái độ dựa trên Lý thuyết của Martin và White (2005). Hơn nữa, cách tiếp cận ngôn ngữ chức năng hệ thống của White (1998) đã được sử dụng để khai thác cả ý nghĩa kinh nghiệm và liên nhân của văn bản tin tức với việc sử dụng ngữ pháp từ vựng làm công cụ phân tích. Một đặc điểm quan trọng của ngôn ngữ đánh giá về thái độ đã được thể hiện rõ nét sau khi phân tích là sự thống trị của ngôn ngữ đánh giá mang tính tiêu cực trong cả hai bài viết khi đề cập đến mức độ nghiêm trọng của đám cháy cùng với sự thụ động trong cách đối phó và tìm ra giải pháp của chính quyền địa phương. Một kết luận khác được rút ra từ nghiên cứu là việc cả hai văn bản đều sử dụng các từ định lượng trong biểu hiện thái độ với mục đích nhấn mạnh việc Amazon đã bị phá huỷ nghiêm trọng.

Tù khoá: lý thuyết đánh giá, ngôn ngữ đánh giá, thái độ, bản tin, thể loại 


\section{APPENDIX}

\section{Appendix 1: The English Article}

Amazon burning: Brazil reports highest forest fires since 2010

BRASILIA - Wildfires raging in the Amazon rainforest have jumped this year, with 72,843 fires detected so far by Brazil's space research center INPE, as concerns grow over right-wing President Jair Bolsonaro's environmental policy.

The surge marks an $83 \%$ increase over the same period of 2018, the agency said on Tuesday, and is the highest since 2010 .

Since Thursday, INPE said satellite images spotted 9,507 new forest fires in the country, mostly in the Amazon basin, home to the world's largest tropical forest seen as vital to countering global warming.

Images show the northernmost state of Roraima covered in dark smoke. Amazonas declared an emergency in the south of the state and in its capital Manaus on Aug. 9. Acre, on the border with Peru, has been on environmental alert since Friday due to the fires.

Wildfires have increased in Mato Grosso and Para, two states where Brazil's agricultural frontier has pushed into the Amazon basin and spurred deforestation. Wildfires are common in the dry season, but are also deliberately set by farmers illegally deforesting land for cattle ranching.

The unprecedented surge in wildfires has occurred since Bolsonaro took office in January vowing to develop the Amazon region for farming and mining, ignoring international concern over increased deforestation.

Asked about the spread of uncontrolled fires, Bolsonaro brushed off criticism, saying it was the time of the year of the "queimada" or burn, when farmers use fire to clear land. "I used to be called Captain Chainsaw. Now I am Nero, setting the Amazon aflame. But it is the season of the queimada," he told reporters.

Space agency INPE, however, said the large number of wildfires could not be attributed to the dry season or natural phenomena alone. "There is nothing abnormal about the climate this year or the rainfall in the Amazon region, which is just a little below average," said INPE researcher Alberto Setzer. People frequently blame the dry season for the wildfires in the Amazon, but that is not quite accurate, he said. "The dry season creates the favorable conditions for the use and spread of fire, but starting a fire is the work of humans, either deliberately or by accident," Setzer said.

Bolsonaro recently fired the director of INPE after he criticized agency statistics showing an increase in deforestation in Brazil, saying they were inaccurate. "I am waiting for the next set of numbers, that will not be made up numbers. If they are alarming, I will take notice of them in front of you," he told reporters.

Reporting by Lisandra Paraguassu, 


\section{Appendix 2: The Vietnamese Article}

Thảm họa cháy rừng Amazon

Rừng Amazon ở Brazil hứng chịu hàng nghìn đám cháy, khiến khói lan rộng một nửa đất nước, đe dọa cuộc sống của hàng chục triệu dân.

Gần 79.000 vụ cháy rừng đã được ghi nhận ở Brazil trong năm nay, cao nhất kể từ năm 2013, và một nửa trong đó xảy ra tại rừng mưa Amazon, nơi được coi là "lá phổi xanh" của hành tinh. Theo Viện Nghiên cứu Không gian Quốc gia Brazil, riêng hai ngày 23 và 24/8 đã có hơn 1.600 đám cháy mới tiếp tục bùng phát tại Amazon.

Bang Rondonia là một trong những nơi chịu ảnh hưởng nặng nề nhất trong thảm họa cháy rừng, khi người dân phải chung sống với màn khói mù mịt.

Các chuyên gia cho hay việc người dân địa phương phá rừng để làm nương rẫy hoặc chăn thả gia súc trong những tháng mùa khô đã khiến tình trạng cháy rừng trở nên nghiêm trọng hơn.

Theo Viện Nghiên cứu Vũ trụ Brazil, diện tích rừng mưa Amazon bị phá hủy mỗi phút lớn hơn 1,5 sân bóng đá.

Tuần trước, khói và tro từ đám cháy rừng thậm chí bay qua $2.735 \mathrm{~km}$ tới thành phố Sao Paulo, nhuộm đen bầu trời vào ban ngày. Copernicus, chương trình vệ tinh của Liên minh châu Âu, chia sẻ bản đồ cho thấy khói lan tới vùng ven biển Đại Tây Dương của Brazil, bao phủ gần nửa đất nước và tràn sang các quốc gia láng giềng Peru, Bolivia và Paraguay.

Tổng thống Brazil Jair Bolsonaro đã ký sắc lệnh huy động quân đội đối phó các đám cháy và cam kết bảo vệ bằng được rừng Amazon, dù chính phủ của ông bị chỉ trích là phản ứng chậm chạp trước thảm họa. 44.000 binh sĩ Brazil đã được triển khai tới 7 bang, trong đó có Rondonia, để hỗ trợ địa phương dập tắt các đám cháy. 30 lính cứu hỏa cùng 6 máy bay, gồm 2 chiếc Hercules C-130 có khả năng mang theo 12.000 lít nước mỗi lần cất cánh, cũng tham gia chữa cháy rừng ở Rondonia. Tổng thống Bolsonaro hôm 21/8 đổ lỗi cho các tổ chức phi chính phủ gây ra các vụ cháy, tuy nhiên sau đó một ngày, ông nói rằng các nông dân có thể là thủ phạm dẫn tới thảm họa này.

Thảm họa ở rừng mưa lớn nhất thế giới đang gây ra một làn sóng phẫn nộ toàn cầu, làm dấy lên các cuộc biểu tình thu hút hàng nghìn người ở Brazil lẫn các nước châu Âu. Tại hội nghị thượng đỉnh G7 ở miền nam Pháp cuối tuần qua, các lãnh đạo của nhóm các nước công nghiệp phát triển, đã nhất trí hỗ trợ càng sớm càng tốt những quốc gia chịu ảnh hưởng do cháy rừng mưa ở Amazon. Tổng thống Mỹ Donald Trump và Thủ tướng Anh Boris Johnson trước đó cũng đã đề nghị giúp đỡ Brazil khống chế thảm họa cháy rừng.

(This report was taken from vnexpress.net) 